\title{
Е.Г. Водичев
}

\section{В ТЕХНОЛОГИЧЕСКОМ ТУПИКЕ: ОТРАСЛЕВАЯ НАУКА НА ВОСТОКЕ СССР ВО ВТОРОЙ ПОЛОВИНЕ 1940-х гГ.}

\author{
Статья подготовлена при финансовой поддержке РФФИ (проект № 18-011-00170 \\ «Наука и ученые в восточных регионах России в мобилизачионной парадигме (1930 - начало 1950-х г2.)»).
}

\begin{abstract}
Характеризуется ситуация в «гражданском» сегменте отраслевой науки в восточных регионах СССР в условиях сохранявшейся в послевоенные годы «мобилизационной» парадигмы развития. Анализ проведен на фоне экономических и технологических «вызовов» послевоенного времени и их отражения в советской научно-технической «протополитике». Особое внимание уделяется характеристике сети науки научных учреждений в отраслевом и территориальном разрезах. Сделан вывод о принципиальном несоответствии потенциала «гражданской» отраслевой науки масштабу стоящих перед научнотехническим комплексом страны и региона задач.

Ключевые слова: отраслевая наука; технологические вызовы; поздний сталинизм; восточные регионы СССР; мобилизационная парадигма.
\end{abstract}

Общая характеристика экономических «вызовов» послевоенного времени. Завершение Второй мировой войны обернулось для Советского Союза политическим триумфом, сопряженным с тяжелыми экономическими и социальными последствиями. Наряду со многими другими задачами, в стране предстояло довести до логического завершения индустриализацию в тех секторах, где накануне войны так и не был достигнут современный уровень индустриального производства. Это касалось почти всех отраслей машиностроения, за исключением тяжелой промышленности, транспорта (хотя развитие транспортной инфраструктуры и сети коммуникаций оставалось крайне неудовлетворительным) и военной индустрии в целом. Однако для достижения стратегических перспектив было необходимо решить еще одну, связанную с первой, проблему - обеспечить переход экономики на новый технологический уровень.

Последнее требовало системности и комплексности при формировании стратегии экономического развития. Окончание войны оставляло шанс для восстановления производства с одновременным изменением его структуры и повышением технологической культуры, проведением масштабной реконверсии, усилением социального вектора экономического развития. Этого, однако, не произошло, и после завершения реконструктивных процессов советская экономика оставалась крайне милитаризованной, а реконверсия была далеко не полной. СССР сохранял экономику воюющей страны, а структура и характер развития экономического потенциала совершенно не отвечали задачам мирного времени.

Начавшаяся в 1946 г. «холодная война» служила оправданием для высокого уровня милитаризации производственного потенциала СССР. Однако не следует сбрасывать со счетов и тот факт, что такой тип мобилизационной экономики стал «родовым признаком» сталинского режима, не изменившись и в первые послевоенные годы. На «внешних врагов» в условиях формирующегося биполярного мира списывалась невозможность обеспечить усиление социальных направлений в развитии экономики, а о модификации модели взаимоотношений власти, государства и общества вопрос вообще не стоял.

Весьма противоречивым оставался и подход к территориальным пропорциям экономического развития. Напомним, что задача сдвига производственного потенциала на восток предусматривалась еще в 1930-е гг. в рамках первых пятилетних планов. Чрезмерная концентрация производства в центральных и западных регионах правомерно рассматривалась как фактор, сдерживающий экономическое развитие, формирующий социально-политические диспропорции и создающий потенциальную угрозу национальной безопасности. Наиболее перспективными в плане размещения производительных сил считались восточные регионы России.

Как известно, война привела к фантастическому по своим масштабам перемещению производственной базы на восток и юго-восток, за тысячи километров от прежнего «хартленда», который исторически формировался в континентальной империи на протяжении столетий. Парадоксальным образом в результате войны было достигнуто такое изменение пропорций в развитии потенциала восточных территорий, которое вряд ли бы удалось осуществить за десятилетия мирного развития. Уровень производственного потенциала периферийных регионов существенно возрос. Реэвакуация не была полной: на востоке и юго-востоке, на Урале, в Сибири, в Казахстане остались многочисленные промышленные предприятия. Однако по большей части они принадлежали к военному сектору экономики, и в силу своей «закрытости» не могли стать основой для комплексного развития территорий размещения. Если ко времени окончания войны для военнопромышленного комплекса (ВПК) результаты масштабного сдвига производственной базы на восток были очевидными, то в «гражданских» секторах экономики эта задача вновь отодвигалась на перспективу. К тому же планируемый там «восточный сдвиг» отражал прежде всего «нарастающую потребность в сырьевых и энергетических ресурсах, которую испытывали развитые западные районы CCCP» [1. C. 144]. 
После окончания войны прежняя экономическая модель со всеми особенностями, присущими индустриализационному варианту развития на основе мобилизационной парадигмы, сформировавшаяся еще в 1930-е гг., в целом восстанавливалась [2. С. 21-59]. Сохранялись старые подходы и к структуре производства, и к инвестиционным приоритетам - развитие экономики осуществлялось, как и прежде, за счет возрастающей нагрузки на население страны. Во всяком случае, именно на этой основе строились проектировки послевоенных пятилетних планов. Акценты попрежнему расставлялись в пользу приоритетного развития тяжелой промышленности, а наукоемкое производство оставалось «за кадром», по крайней мере в «гражданских» секторах экономики [3. С. 4]. Как выяснилось впоследствии, сохранение прежних приоритетов оказалось крайне затратным. «В одну и ту же реку нельзя войти дважды - за масштабное и насильственное изъятие продовольствия в течение четверти века, между 1928 и 1953 гг., на протяжении последующих десятилетий придется дорого платить» [4. C. 327-328]. Но в первые послевоенные годы постановка вопроса о смене приоритетов развития перспектив явно не имела.

Технологические «вызовы» и особенности научно-технической политики. Не менялись и технологические приоритеты в гражданском сегменте экономики. Объективно перед советской экономикой стояла задача масштабного перехода на более высокий технологический уровень. Если анализировать зарубежные тренды, то фактически речь должна была идти об ускоренном формировании нового технологического уклада внутри советской экономической системы. В передовых экономиках Запада высокие темпы технологического обновления производства стали сочетаться с фронтальным научно-техническим прогрессом, вышедшим за рамки относительно узкого набора приоритетов, имеющих преимущественно оборонное значение. Принцип «ведущего звена» отошел в прошлое, а технико-технологический прогресс в экономике стал приобретать более сбалансированный и системный характер. Такой уровень системности для советской экономики с жесткими акцентами на производстве средств производства и доминированием отраслей ВПК оказался недостижим.

Формирование нового технологического уклада было невозможным без ускоренного развития новой техники, технологий, инноваций в целом. Однако в экономической политике послевоенного времени этим вопросам не уделялось сколько-нибудь достойного внимания. Да и о какой-либо технической политике, а тем более научно-технической или инновационной, можно было говорить лишь с высокой долей условности [5]. Существовала лишь некая «протополитика», в рамках которой в первые послевоенные годы проблема генерирования инноваций явно не относилась к числу приоритетных. В историографии справедливо утверждается, что «...по-прежнему, если не на словах, то на деле адаптация зарубежного научно-технического опыта и форсированное наращивание на этой основе экономических возможностей страны рассматривались в качестве первоочередной задачи» [6. С. 49].
Очевидным исключением из этого правила являлись лишь ряд секторов военно-промышленного комплекса, хотя и там при решении «задач номер один, номер два и номер три», связанных с разработкой ядерного оружия, средств его доставки и систем наведения, использование зарубежного опыта некоторое время являлось важнейшим инструментом. Осознание необходимости формирования собственной научнотехнической базы происходило постепенно, по мере продвижения вперед в решении «оборонных» задач [7].

В 1940-е - начале 1950-х гг. научно-технический прогресс носил в стране «островной» характер, не выходя в сколько-нибудь существенной мере за рамки военно-промышленного комплекса. В то же время трансферт ноу-хау и технологий в «гражданские» сектора экономики оставался практически заблокированным из-за завесы секретности, высочайших ведомственных барьеров, атмосферы подозрительности и шпиономании. Там воспроизводился прежний технологический уклад. При этом крайне слабой оставалась фундаментальная основа для развития техникотехнологического прогресса - развитие научных исследований, ориентированных на «гражданские» отрасли экономики. Несмотря на быстрое количественное увеличение ряда показателей научного потенциала, таких как численность научных учреждений и научно-технического персонала, в стране отсутствовала единая научно-техническая политика как совокупность целей и задач по использованию научноисследовательских и опытно-конструкторских работ для обеспечения приоритетов государственного развития [8. С. 444-445].

В то же время формирование технической политики на основе заимствованных технологий могло оставаться актуальным лишь на протяжении относительно короткого времени. Во-первых, зарубежные источники получения оборудования, как и сроки, в течение которых вывоз технологий оставался возможным, были крайне ограниченными и уже в 1946 г. со всей очевидностью показали свои пределы. Во-вторых, вывоз технологий касался все же весьма небольшого количества отраслей и не мог решить проблемы повышения технологической культуры всей экономики страны. В-третьих, зависимость производств от технологий, не имеющих собственной научной базы внутри страны, представлялась чрезвычайно рискованной, особенно в военно-технической сфере и машиностроении, основе производственного потенциала экономики [9. С. 167].

Опираясь на заимствованные технологии, очень скоро страна рисковала оказаться в технологическом тупике. Выходом из такой ситуации могло стать только ускоренное развитие собственной научнотехнической и технико-технологической инфраструктуры. Начиная с первых послевоенных лет формирование такой базы форсированными темпами происходило в ключевых отраслях ВПК, но, как уже отмечалось, в условиях заблокированного перетока научнотехнологических решений в «гражданские» сектора, в остальном в первое послевоенное десятилетие советская экономика явно переставала соответствовать духу времени. Представляется справедливым мнение 
тех специалистов, кто делает вывод «о недооценке на официальном уровне роли отечественной науки в технико-технологическом прогрессе» [6. С. 51].

Характер экономического потенциала на востоке СССР. В полной мере это касалось и восточной макрозоны страны, экономическая ситуация в которой оставалась в послевоенные годы весьма сложной. Массовая реэвакуация промышленных предприятий на места их прежней дислокации не была полной - значительная их часть из стратегических соображений оставалось на территории востока СССР. Фактически в регионе, как и в стране в целом, сформировался огромный «Архипелаг ВПК» со своей собственной системой научно-технического и технико-технологического обеспечения, выросший в окружении предприятий, действовавших в рамках устаревших технологических укладов, и практически изолированный от прочих сегментов региональной экономики.

Именно там и коренилось большинство проблем для региона. В литературе отмечается, что «интенсифицируя оборонное производство, война резко затормозила развитие традиционной экономики в регионе. ...Война отрицательно сказалась на состоянии местной промышленности, всех видов транспорта. Чрезвычайные обстоятельства военного времени имели краткосрочное влияние на темпы индустриального развития Сибири. Они в дальнейшем затормозились в связи с процессами реконверсии, а в некоторых важнейших промышленных центрах наблюдалось даже снижение выпуска валовой продукции. ... Отрицательные последствия войны сказывались на экономике Сибири вплоть до середины 50-х гг., а некоторые и до сих пор, поскольку на ее территории оказались производства, которые в мирное время здесь никто бы не стал создавать» [10. С. 14].

Экономическое развитие восточных регионов СССР во второй половине 1940-х - начале 1950-х гг. отличалось определенной спецификой по сравнению с европейской частью России. Несмотря на отсутствие оккупации и массовых разрушений основных фондов, к началу первого послевоенного десятилетия в общем и целом экономическая ситуация на востоке была хуже. Промышленность здесь оказалась более милитаризованной, соответственно задачи реконверсии носили более сложный и глубокий характер.

К тому же в первые послевоенные годы изменились воспроизводственные пропорции в экономике и межрегиональное перераспределение ресурсов. Инвестиции перераспределялись в регионы, в наибольшей степени пострадавших от военных действий и оккупации. В результате совокупная доля Сибири и Дальнего Востока в капиталовложениях в 1946-1950 гг. существенно снизилась по сравнению с предвоенным периодом.

Следует также отметить, что в Сибири наметилась тенденция существенного более высокого роста отраслей топливно-энергетического комплекса по сравнению с промышленностью в целом. Во второй половине 1940-х гг. экономический профиль восточных регионов страны изменился. В промышленности Сибири и Дальнего Востока снизился удельный вес чер- ной металлургии, машиностроения и металлообработки, химической промышленности, легкой промышленности. Напротив, доля отраслей, производящих первичное сырье (угольная промышленность, лесоразработка и деревообработка, цветная металлургия и др.), повысилась [11. С. 28-31]. В результате усилилась ресурсная ориентация экономики региона.

Однако уже к началу 1950-х гг. на экономическом горизонте все более отчетливо проступали социальноэкономические ограничения стратегий, ориентированных лишь на использование Сибири как сырьевого придатка европейской России. Возникли новые проблемы и в экономическом комплексе страны в целом. С одной стороны, чрезмерная концентрация перерабатывающих отраслей промышленности в центральной и западной частях СССР при постоянном увеличении масштабов производства приводила к огромному перенапряжению транспортных потоков. С другой стороны, деформированная структура производства внутри Сибирского региона все сильнее ограничивала перспективы его дальнейшего роста, формируя не только экономические, но и социальные вызовы и повышая экологическую нагрузку на среду обитания до недопустимого уровня. К тому же сами по себе ресурсные отрасли экономики региона нуждались в рационализации, техническом перевооружении и значительном росте эффективности производства.

В целом же изменение территориальных акцентов в развитии экономики по сравнению с предвоенным периодом для восточной макрозоны России обернулось значительно более низкими темпами экономического развития. Постепенно приходило понимание, что данная ситуация представляет большую опасность для экономического комплекса страны в целом. В целях преодоления сложившейся асимметрии вновь был акцентирован курс на ускоренное развитие восточных регионов страны, прежде всего Сибири и Дальнего Востока.

Отраслевая наука региона: возможности и ограничения. Масштабность экономических вызовов, стоящих перед экономикой восточных территорий страны, требовала адекватных инструментов для «расшивки» проблемных ситуаций. Многое упиралось в остро вставшую проблему научно-технического и технико-технологического обеспечения производства и социально-экономического развития в целом. Решение ее в рассматриваемый период оказалось связанным со значительными сложностями. Как уже отмечалось, рассчитывать на трансферт технологий от предприятий ВПК в «гражданскую» экономику не приходилось. Возможности использования в регионе зарубежных технологий также были весьма ограниченными. К тому же возникала проблема адаптации зарубежной техники и технологических решений. Именно ее, наряду с разработкой собственных научно-технических и технико-технологических решений, что уже в краткосрочной перспективе должно было стать гораздо более важным фактором развития экономики, предстояло решить отраслевой науке.

Основной груз ответственности должны были взять на себя центральные научно-исследовательские учреждения (НИУ) соответствующих ведомственных 
вертикалей, по большей части в рассматриваемый период расположенные в центре страны. Однако при этом оставалась не менее сложная задача регионализации научных и технико-технологических разработок для использования в суровых условиях локализованных в Сибири предприятий. Решать ее предстояло отраслевой науке региона, а также ограниченному сегменту «заводской науки», комплексу научнотехнических подразделений субъектов экономической деятельности, которые также зачастую рассматривают в рамках отраслевого сегмента научного потенциала. Вопрос заключался в том, в какой мере «гражданская» отраслевая наука восточных территорий СССР была готова к решению такой задачи.

Основные организационные тенденции в развитии отраслевой науки в восточных регионах России были производными от общей стратегии научнотехнического развития страны. Именно в отраслевой науке в наибольшей степени проявилось стремление перенести в эту сферу складывающиеся в годы первых пятилеток хозяйственные практики. Принцип приближения институтов к производственной базе был сформулирован еще накануне первой пятилетки. Став отправной точкой научно-организационной стратегии, он определял территориальный сдвиг науки на восток, ближе к реальному производству. Ускоренное «освоение» восточных регионов страны отраслевой наукой обозначилось еще в 1930-е гг., однако на протяжении всего предвоенного десятилетия оно носило крайне противоречивый характер [12. С. 136-147]. Локализация НИУ была обусловлена аргументами отдельных ведомств, однако с точки зрения региональной и общенаучной целесообразности она зачастую оказывалась далеко неоптимальной.

Вторая мировая война существенно изменила территориальный профиль отраслевой науки. В годы войны произошло массированное перемещение на восток не только промышленных предприятий, но и многочисленных НИУ. Сеть учреждений отраслевой науки в регионе, в особенности в Западной Сибири, существенно увеличилась, причем это касалось как индустриальных, так и аграрных и медицинских институтов, отделений и филиалов. В целом война создала научно-организационные предпосылки ускоренного продвижения науки на Урал и в Сибирь и формирования здесь новых научных учреждений.

Но главным образом передислокация промышленных предприятий на восток обусловила быстрое развитие в регионе научных учреждений, обслуживающих оборонный комплекс, которые в том или ином виде остались в местах нового размещения и после окончания войны. Однако, как и в сфере промышленного производства, в послевоенные годы граница между «оборонным» сегментом отраслевой науки, и ее «гражданской» частью оставалась незыблемой.

Как часть вертикально интегрированных производственных комплексов, подчиненная в организационном отношении соответствующим ведомствам, отраслевая наука была тесно связана с реальным сектором экономики. Именно здесь можно было ожидать наибольших корреляций между локализацией научных учреждений и производством. Логично предпо- ложить, что отраслевая наука в гораздо большей мере, чем другие сегменты советской научной системы, отразит в своем пространственном развитии объективные потребности экономических трансформаций.

Традиционно основной характеристикой при исследовании институциональных аспектов развития науки является анализ структуры ее сети и кадрового потенциала. Исходя из теоретических предпосылок, для восточных регионов России институциональные трансформации должны были означать опережающий рост сети и кадрового потенциала локализованных там отраслевых НИУ, изменение структуры сети в пользу наиболее эффективных и устойчивых ее компонентов, обеспечение тесной корреляции между профилем производственной деятельности и спецификой реализуемых в отраслевых НИУ научноисследовательских и опытно-конструкторских работ (НИОКР). Произошло ли это на самом деле и насколько реальная ситуация соответствовала теоретическим построениям? Ответы на эти вопросы позволяли оценить возможности отраслевой науки решать объективно стоящие перед регионом социальноэкономические и социокультурные задачи.

После окончания войны сеть научных учреждений, подчиненных различным ведомствам, на территории Сибири была довольно обширной. По имеющимся данным, к 1946 г. в регионе действовало 94 НИУ различной ведомственной принадлежности, без учета учреждений АН СССР, а также архивов и музеев, работавших практически в каждом республиканском, краевом и областном центре [12. С. 235, 237]. Статус «научных» на такие учреждения можно было распространить лишь с большой долей условности. Вместе с тем, лишь 1/5 часть всех НИУ состояла из самостоятельных научно-исследовательских институтов (16 НИИ) и их отделений и филиалов (4 НИУ). Институты и филиалы составляли ядро научного потенциала отраслевой науки, в них работала почти половина всех научных работников ведомственных НИУ. В то же время свыше 2/3 от общего количества отраслевых НИУ (65 учреждений) Сибири было представлено опытными и научно-исследовательскими станциями, опорными пунктами, опытными полями и питомниками.

Сеть отраслевых НИУ в Сибирском регионе отличалась определенным своеобразием. Несмотря на явное доминирование в составе региональных НИУ таких незначительных по размеру, слабых по своему потенциалу и, как правило, не ведущих самостоятельных НИОКР учреждений, как опытные и научноисследовательские станции, опытные поля, питомники и заповедники, она включала в себя, как отмечалось выше, довольно значительную часть НИИ и их филиалов. Некоторые из них были достаточно крупными по меркам учреждений отраслевой науки. Так, например, в филиале Макеевского НИИ по безопасности работ в горной промышленности работало 34 сотрудника, правда, научных работников среди них было всего семь. В Сибирском филиале Всесоюзного научно-исследовательского маркшейдерского института работало всего шесть научных сотрудников. Никто из них не имел ученых степеней и званий 
[13. Л. 37]. Оба института находились в ведении Министерства угля СССР.

Были исключения и среди научноисследовательских станций. Они относились в основном к учреждениям, расположенным в полярных районах и находившихся в ведении Главсевморпути. Например, штат полярной станции «Диксон» состоял из 116 чел., «Мыс Челюскина» - 44 чел. (обе территориально относились к Красноярскому краю). Значительная численность работающих была характерна и для селекционных станций Министерства земледелия СССР. В Алтайском крае в таких НИУ в Барнауле и Славгороде в совокупности работало более 300 чел., но лишь 14 из них являлись научными сотрудниками. В Восточной Сибири в аналогичных учреждениях в поселке Солянка (Красноярский край) и г. Тулун (Иркутская область) работало более 250 чел. в каждом. Количество научных сотрудников также было ограничено 15 и 10 специалистами. Крупнейшей селекционной станцией в Сибири являлась ЛенинскКузнецкая в Кемеровской области - 323 работника, в том числе семь научных сотрудников [13. Л. 89].

Размещение отраслевых НИУ по территории Сибирского региона на макроуровне было почти равным в западной и восточной частях региона при некотором превышении удельного веса Восточной Сибири по общему количеству НИУ. Самостоятельные НИИ равномерно распределялись между двумя частями Сибири. Половина от общего числа НИИ была представлена научно-исследовательскими институтами медицинского профиля, которые действовали в Омске, Новосибирске, Томске, Красноярске, Иркутске и Чите. Особенностью Восточной Сибири был высокий удельный вес отраслевых институтов гуманитарного профиля. Они составляли ${ }^{1 /}{ }_{4}$ часть всех отраслевых институтов. Эти НИИ работали в национальных автономиях Восточной Сибири - в Абакане, Кызыле, Якутске и Улан-Удэ - при правительствах соответствующих автономных республик и областей. Следует отметить, что к 1951 г. количество таких НИИ возросло уже в Западной Сибири, за счет формирования Горно-Алтайского научно-исследовательского института истории, языка и литературы (НИИЯЛИ). Такие комплексные научные учреждения гуманитарного профиля в 1930-е - 1950-е гг. создавались в большинстве национальных автономий СССР [14. С. 451-452].

Эти же НИИ среди других отраслевых научных учреждений обладали и наиболее квалифицированным кадровым составом. Например, в 1946 г. в Якутском НИИЯЛИ из 18 научных сотрудников пятеро имели степени кандидатов наук, в расположенном в Абакане (Красноярский край) Хакасском НИИЯЛИ работало 12 научных сотрудников, в том числе три кандидата наук, в Тувинском НИИЯЛИ в Кызыле из пяти научных работников двое были кандидатами наук [13. Л. 54-55].

В конце 1940-х - начале 1950-х гг. в западной части Сибирского региона крупными научноисследовательскими организациями являлись действовавший в Новосибирске Институт мер и измерительных приборов, переведенный в этот город из Томска, подведомственный ВАСХНИЛ Сибирский
НИИ зернового хозяйства в Омске и Сибирский НИИ животноводства в Новосибирске, а также Кузнецкий научно-исследовательский угольный институт в г. Прокопьевске Кемеровской области. В крупнейших городах Западной Сибири действовало четыре НИИ медицинского профиля [12. С. 235-236].

Некоторые из этих институтов возникли еще в 1930-е гг., другие, в особенности относящиеся к высокотехнологичным секторам производства, что, однако, для «гражданского сегмента» отраслевой науки было большой редкостью, сформировались в годы войны и быстро развивались в послевоенные годы. В этом плане типичной является история Института мер и измерительных приборов, начавшего свою деятельность в 1944 г. Уже за рамками рассматриваемого периода, к середине 1950-х гг. на базе этого НИИ возникла вторая метрологическая база СССР, что позволило ему в дальнейшем претендовать на роль главного центра эталонов в некоторых областях измерений и эталонной базы на востоке России [15. С. 774].

Крупными научными учреждениями считались филиалы институтов горнодобывающего профиля, расположенные в Кузбассе, Прокопьевске и ЛенинскКузнецке (уже упоминавшиеся Кузнецкий угольный институт, филиал Макеевского НИИ и Сибирский филиал Всесоюзного научно-исследовательского маркшейдерского института), а также отделение ВНИИ озерного и речного хозяйства в Тобольске, Тюменской области. Аналогичное учреждение работало и в Якутии, на востоке региона.

В Восточной Сибири одним из крупнейших отраслевых НИИ являлся Иркутский институт редких и цветных металлов («Иргиредмет») Министерства цветной металлургии СССР, созданный еще в 1930-м г. и претерпевший в годы войны ряд реорганизаций. Институт занимался исследованиями и разработками в интересах золотодобывающей промышленности, имел собственную экспериментальную и производственную базу.

В количественном отношении среди НИИ Восточной Сибири весомую долю занимали учреждения медицинского и санитарного профиля. В Иркутске работало сразу несколько медицинских НИИ - Институт эпидемиологии и микробиологии (аналогичный институт работал и в Красноярске), Иркутский институт травматологии и ортопедии, Противочумный институт, Ангарский НИИ гигиены труда и профзаболеваний. Ведущим учреждением санитарно-гигиенического профиля в Забайкалье являлся Читинский институт эпидемиологии и микробиологии [16. C. 215-216]. Однако в целом в системе отраслевой науки Сибири доминировали учреждения сельскохозяйственной науки, в основном опытные станции и поля [13. Л. 1-163].

Если же рассматривать территориальный «срез» сети отраслевой науки на востоке России в более широкой проекции, добавляя к исходным данным сведения и по Уральскому, и по Дальневосточному регионам, то здесь наблюдается в целом ожидаемая картина. Обращают на себя внимание два обстоятельства. Во-первых, тот факт, что на Урале (в границах Уральского экономического района, т.е. в то время включая 
Башкирскую АССР) работало приблизительно столько же НИУ, сколько в Сибири и на Дальнем Востоке вместе взятых. При этом большая часть таких учреждений была сосредоточена на Среднем Урале, в Свердловской области (23 из 33 НИУ учитываемого в статистических расчетах типа). В Свердловске было расположено больше всего самостоятельных НИИ, а также филиалов, отделений лабораторий других НИИ среди всех регионов восточной части страны. Очевидно, что в первые послевоенные годы именно Свердловск, с учетом действующих там Уральского филиала АН СССР и значительного количества вузов, с полным основанием мог претендовать на роль «научной столицы» российской периферии. Кроме Свердловска, уральские НИУ размещались также в Уфе, Молотове (Перми) и Чкалове (Оренбурге).

Во-вторых, очевидна тенденция уменьшения количества НИУ при продвижении с запада на восток. Однако внутри сибирских регионов она имела сглаженный характер: в Западной Сибири (с учетом Тюменской области) и в Восточной Сибири (включая Якутскую АССР, исходя из действовавших в то время принципов экономического районирования) количество НИУ было практически одинаковым - соответственно, 13 и 12 учреждений), а вот Дальний Восток в этом отношении значительно отставал (9 НИУ). На Дальнем Востоке 2/3 НИУ концентрировались в Хабаровском крае, который в рассматриваемый период представлял собой обширную территорию, включавшую не только современную Амурскую область, но и весь северо-восток РСФСР. 1/3 НИУ территориально располагалась в Приморском крае, во Владивостоке. Дефицит научного обеспечения отдаленных российских территорий на востоке страны со всей очевидностью просматривался даже по данным статистики. При этом хотелось бы подчеркнуть, что статистически учтены лишь самостоятельные НИИ, а также их филиалы, отделения и территориально обособленные лаборатории. Другие научные учреждения, многочисленные, но, за редкими исключениями, не имеющие значительного штата научных работников (научноисследовательские и опытные станции, опытные поля, заповедники, музеи, архивы, библиотеки и т.п.) в данном случае остаются вне поля анализа.

Точками концентрации отраслевых НИУ в Западной Сибири ожидаемо стали два крупнейших промышленных региона - Новосибирск (20,8\% от всех локализованных в Сибири НИУ) и Кемеровская область (12,5\%) и два аналогичных в Восточной Сибири - Красноярский край $(16,7 \%)$ и Иркутская область (12,5\%). Среди всех территориально-административных образований Сибири НИУ учитываемого типа не было лишь в Алтайском крае, хотя в этом преимущественно аграрном регионе работала значительная часть опытных станций и полей сельскохозяйственного направления, которые в данном случае статистикой не учитываются.

Более 1/3 локализованных в регионе НИУ относилось к категории промышленных, обслуживая различные сферы индустриального производства и строительства. Из них 2/3 было расположено в Западной Сибири, и 1/3 - в Восточной. При этом специализированных НИУ в области транспорта и связи в рассмат- риваемый период в Сибири вообще не существовало. Однако ведущая по количеству учреждений группа НИУ (40\%) была все же представлена не промышленными НИИ, а институтами, работавшими в области охраны здоровья и медицины. Они в равной пропорции распределялись между двумя частями Сибири. Значительная часть НИУ (16\%) состояла из учреждений статистической группы «Просвещение и культура». Среди институтов это был уже упоминавшийся НИИЯЛИ [13. Л. 1-163].

Все крупные НИУ, относящиеся к сфере сельскохозяйственного производства, находились в Западной Сибири, в Новосибирске и Омске. В первой половине и середине XX в. Омская область считалась ведущим центром аграрной науки на востоке России. Локализация в Омской области сельскохозяйственных НИУ имела давние исторические корни. Вместе с тем, как уже отмечалось, научные и экспертные возможности еще одного сибирского аграрного региона - Алтайского края - в рассматриваемый период были ограничены лишь небольшим количеством сотрудников опытных полей и научных станций.

Статистический анализ показывает, что сибирские НИУ тяготели к местам размещения предприятий тех отраслей производства, которые они были призваны обслуживать - угольной промышленности (Кемеровская область), машиностроения (Новосибирск, Томск), лесной промышленности (Красноярский край), сельского хозяйства (Новосибирск, Омск), т.е. по большей части ресурсных отраслей. Не менее значимым фактором локализации крупных НИУ являлась развитая городская среда - институты, работающие в сфере медицины и санитарии, распределялись по городам региона относительно равномерно, тяготея, однако, к большим городам (Новосибирск, Иркутск). НИИ культурологического профиля располагались в этнонациональных районах, имея специфическую социокультурную и идеологическую миссию и решая соответствующие задачи (Абакан, Кызыл, Улан-Удэ и Якутск).

Территориальное распределение научных кадров отраслевой науки Сибири практически полностью воспроизводило географию сети НИУ. Численность научных сотрудников, работавших в учреждениях отраслевой науки в западной и восточной частях региона, была практически равной, коррелируя с размещением НИУ в каждой из них.

Реальные возможности структурных компонентов сети НИУ характеризует численность научного персонала в разрезе различных типов научных учреждений. Как уже отмечалось, наиболее высокой концентрация научного персонала была в специализированных НИИ и их отделениях и филиалах, где работала почти половина от общего количества научных сотрудников отраслевой науки Сибирского региона. Именно в таких НИУ были заняты все доктора наук (семь человек на начало 1946 г.) и 2/3 кандидатов наук (57 из 86). Оставшаяся треть специалистов с учеными степенями кандидатов наук являлась сотрудниками опорных пунктов, опытных полей, питомников и заповедников, то есть НИУ сельскохозяйственного профиля. 
Специализированные НИИ обладали достаточно высоким уровнем квалификации персонала - каждый пятый научный сотрудник таких учреждений имел ученую степень доктора или кандидата наук. Для регионального сегмента отраслевой науки в целом соответствующие показатели не превышали и 10\%. Вместе с тем даже в крупных НИИ проблема квалифицированного персонала стояла очень остро. В уже упоминавшемся «Иргиредмете» в 1948 г. лишь 36\% сотрудников имели высшее образование, и только три человека (из 160 работников) обладали ученой степенью кандидатов наук [16. С. 224].

К началу первого послевоенного года отраслевая наука в Сибири вряд ли могла быть отнесена к доминирующему сегменту регионального научного потенциала. Несмотря на то, что именно к отраслевой науке относилось почти $2 / 3$ всех действовавших в Сибири НИУ и вузов, в них, по имеющимся данным, работало менее $1 / 5$ научных работников и менее $8 \%$ тех специалистов, кто обладал ученой степенью кандидата или доктора наук [17. С. 157].

Анализ статистической информации показывает, что в структуре научно-производственного комплекса (НПК) региона в первые послевоенные годы явно доминировали учреждения высшей школы (3 882 научных работника), но не отраслевая наука (963) и тем более не Академия наук (115 научных работников) [17. С. 157]. Хотя это относилось к обеим частям Сибири, межрегиональные различия также были очевидны. При одинаковом количестве научных работников в обеих частях региона в абсолютных показателях, доля научных работников отраслевых НИУ в совокупной численности научных работников региона варьировала в Сибири в широких пределах. В Западной Сибири она составляла всего лишь 17\%, в то время как в Восточной - почти 38\%. В то же время по общему количеству НИУ учреждения науки, расположенные в регионе и подведомственные министерствам и ведомствам, более чем в три раза превышали совокупные показатели вузов и НИУ АН СССР. Это характеризовало структуру сети, отражало реальные возможности отраслевых НИУ и являлось объективным показателем ограниченности потенциала отраслевой науки.

При итоговых выводах, однако, следует отметить один важный момент. В открытой статистике не учитывались данные по НИУ закрытого типа, расположенных на территории восточных регионов страны. Как справедливо отмечает Л.И. Пыстина, это не позволяет получить полные представления о реальном состоянии научного потенциала региона. Очевидно, что такие НИУ отличались от других учреждений отраслевой науки в лучшую сторону практически по всем характеристикам. Примером тому является уже упоминавшийся СибНИА. По случайно попавшим в открытую статистику данным, к 1951 г. в этом НИИ работало около 70 научных работников, в том числе один доктор и восемь кандидатов наук [12. С. 236], что являлось очень хорошим показателем для учреждений отраслевой науки.

Однако все это не касалось «гражданского» сектора отраслевой науки. Во-первых, структура сети от- раслевых НИУ в первой половине 1940-х гг. продолжала оставаться несовершенной и не соответствовала институциональному типу быстро развивающейся науки. На востоке страны доля НИИ в общем количестве НИУ была существенно меньшей, чем в европейской части России, и в особенности в столичных городах, а наиболее слабые сегменты отраслевой науки (такие, например, как опытные поля) были представлены гораздо сильнее. Аналогичным образом в отраслевой науке региона выглядело и ее кадровое наполнение.

Выводы и заключения. Проведенный анализ позволяет сделать несколько выводов. Во-первых, следует отметить, что и в стране в целом сформированный к этому времени потенциал отраслевой науки оказался недостаточным для решения быстро возрастающего объема задач в сфере НИОКР в интересах ускоренного развития восточных территорий страны. Его структура отражала специфику предшествующего «индустриализационного» этапа в локализации научных учреждений, когда институты размещались в центре, а на расположенные на востоке НИУ в основном возлагались задачи по «доводке» техники и технологий, разработанных в центральных НИИ. В новых условиях такие НИИ все более отрывались от своей производственной базы.

Однако решение новых задач оказывалось невозможным и для НИУ, локализованных непосредственно в регионе. И в количественном, и в качественном аспекте потенциал отраслевой науки на востоке СССР существенно уступал соответствующим показателям отраслевых НИУ в центральной части страны. В Сибири действовала лишь небольшая часть самостоятельных институтов. Большинство отраслевых НИУ, представленных станциями, лабораториями, в лучшем случае отделениями и филиалами центральных НИИ, не было самостоятельно в выборе тематики исследования, не имело необходимой исследовательской и опытно-конструкторской инфраструктуры, испытывало постоянные материально-технические и финансовые проблемы и кадровый голод. Кадровый потенциал отраслевых НИУ Сибири в большинстве случаев не позволял им претендовать на весомый вклад в формирование отраслевых стратегий даже в пределах Сибирского региона.

Их способность адекватно удовлетворять не только перспективные, но и текущие потребности производства, локализованного в Сибири, оставалась под большим вопросом. Особенно острой эта задача оказалась для НИУ промышленного и строительного профилей. Имевшийся в регионе научный потенциал, ориентированный на научное обеспечение и сопровождение развития таких отраслей промышленности, как топливно-энергетическая, нефтехимическая, лесохимическая, металлургическая, нуждался в кардинальном укреплении.

Во-вторых, распределение отраслевых НИУ по территории Сибири также не соответствовало намеченным приоритетам в развитии производительных сил. Потенциал отраслевой науки, которым располагал регион, концентрировался в немногих территориальных центрах. Отраслевые НИУ не демонстрирова- 
ли большого стремления к продвижению в регионы перспективного хозяйственного освоения, стремясь «задержаться» в крупных городах и мегаполисах.

В-третьих, в рассматриваемый период в восточных регионах РСФСР активно формировались отраслевые НИУ закрытого типа. Этот сюжет остался за рамками нашего анализа в данной статье. В контексте вышеизложенного отметим лишь, что такие НИУ частично концентрировались в крупнейших городах региона (Свердловск, Новосибирск, Томск, Красноярск), а частично - в создаваемых для решения оборонных задач наукоградах (Свердловская, Челябинская, Томская области, Красноярский край и так далее). Подобные НИУ обладали намного большим потенциалом, чем типичные региональные отраслевые НИУ. Однако, являясь продолжением «оборонных» производств, они, как правило, находились во внерегиональном экономическом, технико-технологическом и научнотехническом пространстве и крайне слабо влияли на состояние «гражданского» сегмента отраслевой науки и технико-технологический уровень предприятий за пределами ВПК.

Анализ институциональных аспектов развития отраслевой науки на востоке страны приводит к пониманию, что сформированный в регионе ко второй половине 1940-х гг. потенциал отраслевой науки не удовлетворял потребностям развития региона. Отраслевая наука не опережала потребности производства, а шла за ними, причем, как правило, с заметным отставанием. Конфигурация сети НИУ ставила под вопрос ее возможности по научному обеспечению производства даже в рамках сложившихся пропорций, не говоря уже об объективных потребностях их скорейшей трансформации. Частично эта проблема компенсировалась ресурсами академической науки, поскольку середина и вторая половина 1940-х гг. стала периодом становления и развития филиалов Академии наук СССР в Западной и Восточной Сибири, ориентированных в основном на изучение ресурсных возможностей востока СССР, но не «завязанных» на отдельные отрасли экономики и социокультурной сферы [18. С. 69-84; 19. С. 107-166]. Однако полностью решить проблему это не могло. Через несколько лет региону предстояло столкнуться с реализаций вновь декларированного курса на ускоренное экономическое развитие восточных территорий, что объективно еще больше повышало градус ожиданий от отраслевой науки. Однако во второй половине 1940-х гг. она, оставаясь в рамках «индустриализационной» парадигмы и продолжая движение в фарватере мобилизационных стратегий, оказалась к этому явно не готова.

\section{ЛИТЕРАТУРА}

1. Алексеев В.В., Алексеева Е.В., Зубков К.И., Побережников И.В. Азиатская Россия в геополитической и цивилизационной динамике XVI-XX века. М., 2004.

2. Водичев Е.Г. Наука на востоке СССР в условиях индустриализационной парадигмы. Новосибирск, 2012.

3. ХІХ Съезд Всесоюзной коммунистической партии (большевиков) // Коммунистическая партия Советского Союза в резолюциях и решениях съездов, конференций и пленумов ЦК (1898-1986). 9-е изд., доп. и исправл. Т. 8: 1946-1955. М. : Политиздат, 1985.

4. Гайдар Е.Т. Долгое время. Россия в мире: очерки экономической истории. 3-е изд. М., 2005.

5. Водичев Е.Г. Советская научная политика в период «позднего сталинизма» (вторая половина 1940-х - начало 1950-х гг.: маркеры и метаморфозы // Вестник Томского государственного университета. История. 2014. № 2 (28).

6. Артемов Е.Т. Научно-техническая политика в советской модели позднеиндустриализационной модернизации. М. : РОССПЭН, 2006.

7. Артемов Е.Т. Атомный проект в координатах сталинской экономики. М., 2017.

8. Водичев Е.Г., Красильников С.А. Наука на Востоке России // Историческая энциклопедия Сибири. Новосибирск, 2009. Т. 2.

9. Козлов Б.И. Академия наук СССР и индустриализация России: Очерк социальной истории. 1925-1963. М., 2003.

10. Сибирь на пороге нового тысячелетия. Новосибирск, 1998.

11. Экономические проблемы развития Сибири. Методологические проблемы развития и размещения производительных сил. Новосибирск, 1974.

12. Научно-образовательный потенциал Сибири в первой половине XX в. динамика и механизмы развития. Новосибирск, 2009.

13. Российский государственный архив экономики (РГАЭ). Ф. 1562. Оп. 17. Д. 1184.

14. Водичев Е.Г., Узбекова Ю.И. Научно-исследовательские институты языка, литературы и истории // Историческая энциклопедия Сибири. Новосибирск, 2009. Т. 2.

15. Энциклопедия «Новосибирск». Новосибирск, 2003.

16. Казарин В.Н. Образование, наука и интеллигенция в Восточной Сибири (вторая половина 40-х - середина 60-х гг. ХХ в.). Иркутск, 1998.

17. Пыстина Л.И. Научные кадры Сибири: в 1946-1956 годах // Кадры науки советской Сибири: проблемы истории. Новосибирск, 1991.

18. Водичев Е.Г., Красильников С.А., Ламин В.А. и др. Российская академия наук. Сибирское отделение. Исторический очерк. Новосибирск, 2007.

19. Аблажей Н.Н., Букин С.С., Водичев Е.Г., Ламин В.А., Тимошенко А.И. Экономические и социокультурные взаимодействия в УралоСибирском регионе. Новосибирск, 2004.

Статья представлена научной редакцией «История» 29 августа 2018 г.

\section{IN THE TECHNOLOGICAL DEAD END: BRANCH SCIENCE IN THE EAST OF THE USSR IN THE SECOND HALF OF THE 1940S}

Vestnik Tomskogo gosudarstvennogo universiteta - Tomsk State University Journal, 2018, 436, 139-147.

DOI: $10.17223 / 15617793 / 436 / 16$

Evgeny G. Vodichev, Novosibirsk State Technical University (Novosibirsk, Russian Federation); Trofimuk Institute of Petroleum Geology and Geophysics of the Siberian Branch of the Russian Academy of Sciences (Novosibirsk, Russian Federation). E-mail: vodichev@mail.ru

Keywords: branch science; technological challenges; late Stalinism; eastern regions of the USSR; mobilization paradigm.

The paper aims to characterize the civilian segment of the branch science in the East of the USSR after the end of WWII, and assess the capabilities of the branch research and development (R\&D) institutions to cope with new scientific, technical and technolog- 
ical issues of the time. The set of the research questions of the paper includes the analysis of the branch science network structure, and reconstruction of the profile and human potential of the research establishments. The study is conducted taking into consideration the specifics of economic and technological challenges that the country faced in the second half of 1940s, and their reflection in S\&T "protopolicy". In the course of this study, the author relied on generic research methods, as well as historical and statistical methods, and used data from the federal and local archives. As a result of the research, the following conclusions have been made. After the end of WWII, the USSR faced a number of economic challenges. One of the most important was militarization of its economy, and a huge gap between the defense and civilian sectors of the economy, as referred to the technological level of production. In the meantime, the transfer of technologies and know hows between these two sectors was practically blocked. At the first years after the end of the war, the accents in science and technological policy were made on massive utilization of technologies obtained in the West, mostly as reparations. The government underestimated national science and technological (S\&T) policy as a driver of the economic growth in the civilian sector of national economy. Meanwhile, the regional network was very weak and incomprehensible, and incorporated just a limited number of R\&D institutes. The thematic focus of the branch R\&D institutions science did not properly correspond to the profile of the economy as a whole. The policy to bring branch institutions closer to the economics actors in the regions was not successful. During the war and right after the end of the war, the eastern territories became a place of dislocation of numerous classified military production plants, scientific and technological units, but they operated in the "out-of-region" space without significant connections with the civilian branch science and industrial actors. Thus, the capacities of the branch institutes on the East of the USSR were not enough to solve technological issues of the time, not talking about forthcoming challenges connected with the accelerated industrial growth of the eastern territories. The regional segment of the branch science in the civilian sector of the national economy, as well as in the Soviet civilian economics as a whole in the second half of 1940s was still developing in the framework of the algorithms of the 1930s based on the mobilization paradigm, for which comprehensiveness of economic and science and technology decisions had never been a characteristic point.

\section{REFERENCES}

1. Alekseev, V.V. et al. (2004) Aziatskaya Rossiya v geopoliticheskoy i tsivilizatsionnoy dinamike XVI-XX veka [Asian Russia in the geopolitical and civilizational dynamics of the 16th-20th centuries]. Moscow: Nauka.

2. Vodichev, E.G. (2012) Nauka na vostoke SSSR v usloviyakh industrializatsionnoy paradigm [Science in the east of the USSR in terms of the industrialization paradigm]. Novosibirsk: Geo: INGG SO RAN.

3. Fedoseeva, P.N. \& Chernenko, K.U. (eds) (1985) XIX S"ezd Vsesoyuznoy kommunisticheskoy partii (bol'shevikov) [XIX Congress of the AllUnion Communist Party (Bolshevik)]. In: Kommunisticheskaya partiya Sovetskogo Soyuza v rezolyutsiyakh i resheniyakh s"ezdov, konferentsiy $i$ plenumov TsK (1898-1986) [Communist Party of the Soviet Union in resolutions and decisions of congresses, conferences and plenums of the Central Committee (1898-1986)]. 9th ed. Vol. 8: 1946-1955. Moscow: Politizdat.

4. Gaydar, E.T. (2005) Dolgoe vremya. Rossiya v mire: ocherki ekonomicheskoy istorii. 3rd ed. Moscow: Izdatel'stvo AST.

5. Vodichev, E.G. (2014) Soviet Science Policy in the Years of the '’Late Stalinism'” (second half of 1940s - beginning of 1950s): Markers and Metamorphoses. Vestnik Tomskogo gosudarstvennogo universiteta. Istoriya - Tomsk State University Journal of History. 2 (28). (In Russian).

6. Artemov, E.T. (2006) Nauchno-tekhnicheskaya politika v sovetskoy modeli pozdneindustrializatsionnoy modernizatsii [Science and technology policy in the Soviet model of late industrialization modernization]. Moscow: ROSSPEN.

7. Artemov, E.T. (2017) Atomnyy proekt v koordinatakh stalinskoy ekonomiki [Atomic project in the coordinates of the Stalinist economy]. Moscow: Politicheskaya entsiklopediya.

8. Vodichev, E.G. \& Krasil'nikov, S.A. (2009) Nauka na Vostoke Rossii [Science in the East of Russia]. In: Lamin, V.A. et al. (eds) Istoricheskaya entsiklopediya Sibiri [Historical Encyclopedia of Siberia]. Vol. 2. Novosibirsk: Istoricheskoe Nasledie Sibiri.

9. Kozlov, B.I. (2003) Akademiya nauk SSSR i industrializatsiya Rossii: Ocherk sotsial'noy istorii. 1925-1963 [Academy of Sciences of the USSR and the industrialization of Russia: Essay on social history. 1925-1963]. Moscow: Academia.

10. Kuleshov, V.V. (ed.) (1998) Sibir' na poroge novogo tysyacheletiya [Siberia on the threshold of the new millennium]. Novosibirsk: IEiOPP SO RAN.

11. Orlov, B.P. (ed.) (1974) Ekonomicheskie problemy razvitiya Sibiri. Metodologicheskie problemy razvitiya i razmeshcheniya proizvoditel'nykh sil [Economic problems of the development of Siberia. Methodological problems of development and distribution of productive forces]. Novosibirsk: Nauka.

12. Krasil'nikov, S.A. (ed.) (2009) Nauchno-obrazovatel'nyy potentsial Sibiri v pervoy polovine XX v. Dinamika i mekhanizmy razvitiya [Scientific and educational potential of Siberia in the first half of the 20th century. Dynamics and mechanisms of development]. Novosibirsk: Institute of History SB RAS: Novosibirsk State. University.

13. Russian State Archive of the Economy (RGAE). Fund 1562. List 17. File 1184. (In Russian).

14. Vodichev, E.G. \& Uzbekova, Yu.I. (2009) Nauchno-issledovatel'skie instituty yazyka, literatury i istorii [Research institutes of language, literature and history]. In: Lamin, V.A. et al. (eds) Istoricheskaya entsiklopediya Sibiri [Historical Encyclopedia of Siberia]. Vol. 2. Novosibirsk: Istoricheskoe Nasledie Sibiri.

15. Lamin, V.A. (ed.) (2003) Entsiklopediya "Novosibirsk" [Encyclopedia "Novosibirsk"]. Novosibirsk: Novosibirskoe knizhnoe izd-vo.

16. Kazarin, V.N. (1998) Obrazovanie, nauka i intelligentsiya v Vostochnoy Sibiri (vtoraya polovina 40-kh - seredina 60-kh gg. XX v.) [Education, science and intellectuals in Eastern Siberia (the second half of the 1940s-mid-1960s)]. Irkutsk: Irkutsk State University.

17. Pystina, L.I. (1991) Nauchnye kadry Sibiri: v 1946-1956 godakh [Scientific personnel of Siberia: in 1946-1956]. In: Soskin, V.L. (ed.) Kadry nauki sovetskoy Sibiri: problemy istorii [Personnel of the science of Soviet Siberia: problems of history]. Novosibirsk: Nauka.

18. Vodichev, E.G. et al. (2007) Rossiyskaya akademiya nauk. Sibirskoe otdelenie. Istoricheskiy ocherk [Russian Academy of Sciences. Siberian Branch. Historical essay]. Novosibirsk: Nauka.

19. Ablazhey, N.N. et al. (2004) Ekonomicheskie i sotsiokul'turnye vzaimodeystviya v Uralo-Sibirskom regione [Economic and socio-cultural interactions in the Ural-Siberian region]. Novosibirsk: SibAGS. 